Panalungtik: Jurnal yang memuat kajian gagasan dan informasi tentang budaya dan kehidupan masa lalu e-ISSN: 2621-928X

Vol. 1(1) , Juli 2018, pp 1-14 DOI : https://doi.org/10.24164/pnk.v1i1.2

\title{
SIMBOL KEJAYAAN PERKEBUNAN TEH DI INDONESIA: \\ KASUS BANGUNAN BEKAS PABRIK TEH GUNUNG MAS 1910 \\ DI CISARUA, BOGOR
}

\author{
Symbol of Glory of Tea Plantation In Indonesia: \\ Case of Eks Tea Factory Building of Gunung Mas 1910 In Cisarua, Bogor
}

\author{
Lia Nuralia \\ Balai Arkeologi Jawa Barat \\ Jalan Raya Cinunuk Km. 17 Cileunyi Bandung \\ E-mail: liabalar@yahoo.com \\ Naskah diterima 3 April 2018 - Revisi 30 Juni 2018 \\ Disetujui terbit 27 Juli 2018 - Diterbitkan secara online 31 Juli 2018
}

\begin{abstract}
The building of the former Gunung Mas Tea Factory in Cisarua Bogor can provide important information about tea commodities in the past. However, it is feared that it will experience changes in its function and form, so its existence needs to be written down. The purpose of this paper is to describe the symbol of the glory of tea plantations in Indonesia during the Dutch East Indies era, with the case of the former Gunung Mas tea factory. The research method used is descriptive analytical method with interpretation, using a symbolic meaning approach and historical approach, by applying non-verbal communication concept. The results obtained were that factory buildings became a symbol of the glory of tea commodities in the past. The glory is reflected in the physical fruition of flowers and its components show greatness and splendor, which can be interpreted as a symbol of the glory of tea commodities in the past.
\end{abstract}

Key words: Symbol of glory, former tea factory of Gunung Mas, Cisarua-Bogor

\begin{abstract}
Abstrak
Bangunan eks Pabrik Teh Gunung Mas di Cisarua Bogor dapat memberi informasi penting tentang komoditas teh di masa lalu. Akan tetapi, dikhawatirkan akan mengalami perubahan fungsi dan bentuknya, sehingga perlu dituliskan keberadaannya. Tujuan tulisan ini adalah menggambarkan simbol kejayaan perkebunan teh di Indonesia pada zaman Hindia Belanda, dengan kasus eks pabrik teh Gunung Mas. Metode penelitian yang digunakan adalah metode deskriptif analitik dengan interpretasi, menggunakan pendekatan symbolic meaning dan pendekatan sejarah, dengan menerapkan non-verbal communication concept. Hasil yang diperoleh adalah bangunan pabrik menjadi simbol kejayaan komoditas teh di masa lalu. Kejayaan tersebut tercermin dari wujuf fisik bungunan dan komponen-komponennya menunjukkan kebesaran dan kemegahan, yang dapat diartikan sebagai simbol kejayaan komoditas teh di masa lalu.
\end{abstract}

Kata Kunci: Simbol kejayaan, bekas pabrik teh Gunung Mas, Cisarua-Bogor

\section{PENDAHULUAN}

Perusahaan perkebunan teh pernah mencapai puncak kejayaan pada zaman Belanda di awal abad ke-20. Para pengusaha tersebut terkenal dengan sebutan Preanger Planters, yang bermula di daerah Priangan (Jawa Barat). Seperti halnya para pengusaha pabrik gula atau Suikerplanters di Jawa Tengah dan Jawa Timur, Preanger 
Planters berhasil menunjukkan kesuksesannya di Jawa Barat sehingga komoditas teh ketika itu disebut juga sebagai "emas hjau" (Suganda, 2014: vii). Tidak hanya di Priangan, tanaman teh komersial menyebar di pinggiran ibu kota (Batavia). Salah satu perkebunan teh yang populer di Karesidenan Batavia adalah Perkebunan Teh Gunung Mas di Cisarua, Bogor (Afdeeling Buitenzorg)( Staatsblad van Nederlandsch-Indie 1920 No. 723).

Perkebunan Teh Gunung Mas telah berdiri sejak tahun 1910 dan berkelanjutan sampai sekarang. Didirikan oleh orang Perancis yang tergabung dalam perusahaan Societe Franco-Neerlandaise de Culture et de Commerce, di Den Haag (Staatsblad van Nederlandsch-Indie 1920 No. 723). Perusahaan perkebunan Gunung Mas mengalami perubahan dalam berbagai bidang. Setelah zaman kemerdekaan di tahun 1990, melebarkan sayap dengan membuka Agrowisata. Tahun 2009

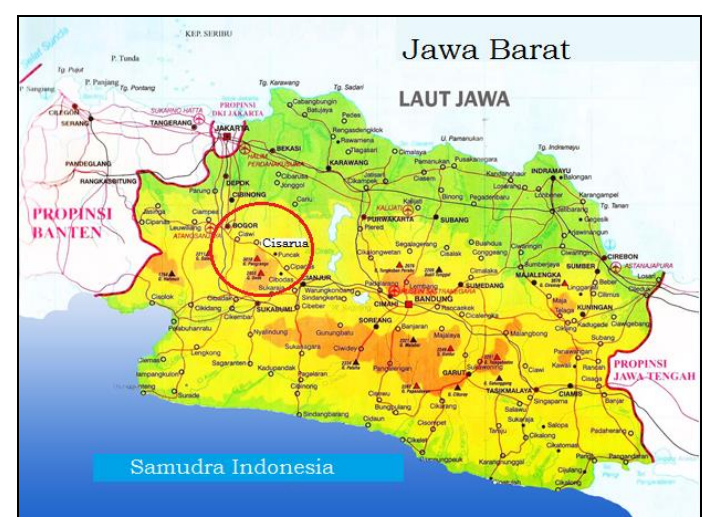

Gambar 1. Lokasi Cisarua Bogor dalam Peta Wilayah Jawa Barat

Agrowisata terpisah secara manajemen dari perkebunan. Kemudian di tahun 2013 pengolahan teh secara mandiri telah dihentikan karena alasan efisiensi. Fungsi bangunan pabrik pun mengalami perubahan menjadi gudang sortasi dan Tea Gallery yang menjual teh siap seduh (Nuralia, dkk., 2013). Galeri Teh Gunung Mas dibuat dengan tujuan sebagai pusat informasi dan show window PTPN VIII, dengan memanfaatkan ruang pabrik yang sudah tidak beroperasi (Ruswandi, 2018).

Perkebunan Gunung Mas menyediakan bahan mentah berupa hasil petik daun teh segar yang kemudian dikirim ke pabrik teh di Perkebunan Tanawatte-Gedeh di Cianjur, untuk diolah menjadi barang jadi berupa teh curah (bulk). Kemudian teh curah dikirim dan dikemas, serta diberi lebel merk dagang ke pabrik pengolahan di Industri Hilir Teh (IHT) Cipadung-Cibiru-Bandung. Teh siap seduh yang dipamerkan dan dijual secara retail di Galeri Teh Gunung Mas ada tiga merk dagang (teh hitam dan teh hijau), sebagai produk PTPN VIII dari berbagai kebun dan pabrik teh di Jawa Barat, yaitu (1) Gunung Mas, (2) Walini, dan (3) Goalpara (Ruswandi, 2018). Perubahan fungsi menyebabkan bangunan pabrik mengalami sedikit perubahan, tetapi secara keseluruhan masih menampakkan keasliannya.

Keberadaan bekas pabrik teh Gunung Mas sekarang masih difungsikan dan dirawat dengan baik, sehingga dapat memberi informasi tentang komoditas teh yang memberi banyak keuntungan di masa lalu. Keuntungan besar yang diperoleh menunjukkan ciri kemajuan atau kejayaan perkebunan teh ketika itu. Jejak-jejak kejayaan di masa lalu tampak di masa sekarang dari wujud fisik bangunan. Apa dan bagaimana 
wujud fisik bekas pabrik tersebut, yang menunjukkan simbol kejayaan perkebunan teh di masa lalu, menjadi permasalahan pokok dalam tulisan ini. Pembahasan dilakukan dengan pendekatan symbolic meaning dan sejarah, dengan menerapkan konsep komunikasi nonverval (non-verbal communicaton concept).

Pendekatan symbolic meaning adalah satu usaha mencari makna (arti) yang terkandung dibalik wujud fisik bangunan, karena bangunan memiliki arti struktural yang dapat berkomunikasi (nonverbal) sebagai arti simbolis dari bangunan tersebut. Semua benda (bangunan) bekerja dalam tiga cara, yaitu melakukan analisis waktu, analisis fungsi, dan analisis penataan objek (Hodder dalam Pearce 2003, 12). Sementara itu, pendekatan sejarah dilakukan dengan memakai data arsip (dokumen, foto dan peta lama), serta informasi lisan yang dituturkan oleh pelaku atau saksi sejarah.

Komunikasi nonverbal adalah komunikasi yang dilakukan secara tidak langsung antara subjek (pembicara/pengamat) dan objek (pendengar/yang diamati). Konsep Komunikasi Nonverbal (non-verbal communication concept) merupakan pemindahan pesan tanpa menggunakan kata-kata secara langsung, dan dianggap merupakan cara paling meyakinkan menyampaikan pesan kepada orang lain. Pesan nonverbal terekam bersamaan oleh penerima pesan sehingga umpan balik merupakan hasil interpretasi pesan tersebut (Wulan, 2015: 224). Makna dari benda-benda budaya dan ekspresi simbolik mengandung pesan dari perilakunya sebagai ekspersi makna non-verbal (Fletcher, 1989 dalam Nuralia, 2017: 4).

Salah satu pesan nonverbal paling penting dari bangunan Belanda adalah gaya aristektur. Arsitektur bangunan awal abad ke-20 umumnya menunjukkan gaya Hindia Baru atau Gaya Indo Eropa (Indo-European Style) yang lebih mengedepankan fungsi, tetapi ciri-ciri gaya arsitektur sebelumnya (Indische Empire Style) masih tampak, sehingga menjadi masa peralihan atau Arsitektur Transisi (1890-1915). Ciri-ciri yang menonjol dalam Arsitektur Transisi adalah denah bangunan simetri penuh, adanya teras depan dan belakang (voor and achter galerij), bangunan tambahan di belakang, bentuk atap limasan, tiang/kolom kayu persegi (Handinoto, 2010: 44).

Pada masa yang sama mulai muncul dan berkembang gaya arsitektur langgam Art Deco, yang digunakan di gedung-gedung perkantoran dan bangunan fungsional lainnya. Salah satu ciri khas dalam bangunan Art Deco menggambarkan maskulinitas dengan garis-garis tegas, suatu hal sangat sulit diciptakan oleh manusia, yaitu garis lurus (https://www.arsitag.com/article/ arsitektur-art-deco,diakses21-02 - 2018 ;10.05 PM).

\section{METODE PENELITIAN}

Metode penelitian yang digunakan adalah metode deskriptif analitik dengan interpretasi, menggunakan pendekatan symbolic meaning Ian Hodder dan pendekatan sejarah, serta menerapkan konsep ilmu 
komunikasi, non-verbal communication concept. Metode deskriptif analitik dengan interpretasi adalah suatu penelitian yang memberikan gambaran tentang realitas pada objek. Dalam hal ini dilakukan deskripsi bentuk dan arsitektur bangunan pabrik, serta tata letaknya dalam permukiman emplasemen perkebunan, kemudian dianalisis memakai non-verbal communication concept. Ada empat tahap pengolahan data dan analisis, yaitu (1) menguraikan sejarah singkat perkebunan, (2) deskripsi singkat bangunan, (3) analisis bentuk, arsitektur, dan tata letak dikaitkan dengan konteks sejarah, dan (4) interpretasi untuk menjelaskan arti dan fungsi.

Pengumpulan data dilakukan melalui studi pustaka, terutama laporan hasil penelitian tahun 2013. Data yang telah ada kemudian dilengkapi dengan gambar dan peta serta informasi terkini ketika penulisan dilakukan tahun 2018 . Data pelengkap diperoleh dari buku, artikel, dan arsip kolonial (dokumen, foto lama, dan lain-lain), serta informasi lisan (wawancara) melalui email dan telepon dengan karyawan perkebunan.

\section{DATA DAN PEMBAHASAN}

Sejarah Singkat Perkebunan Teh Gunung Mas

Perkebunan Gunung Mas merupakan salah satu unit usaha PT Perkebunan Nusantara VIII yang berlokasi di Kecamatan Cisarua, Kabupaten Bogor, Provinsi Jawa Barat. Perkebunan ini merupakan gabungan dari dua perkebunan zaman Belanda, yaitu Gunung Mas (1910) dan Cikopo
Selatan (1912) bernama Perkebunan Gunung Mas (Nuralia dkk 2013).

Perkebunan Gunung Mas dan Cikopo Selatan diberitakan dalam arsip kolonial Het Nieuws van den dag voor Nederlandsch-Indie, 11-11-20 (Staatsblad van Nederlandsch-Indie 1920 No. 723.), berdiri di atas tanah partikelir, tanah milik pribadi, terletak di Puncak, termasuk ke dalam District Buitenzorg, Afdeeling Buitenzorg (Bogor), Residentie van Batavia. Perusahaan ini tergabung dalam Societe Franco-Neerlandaise de Culture et de Commerce, didirikan di Den Haag, dengan "nomor perang" (verpondingsnummer) 1897. Perkebunan Cikopo Selatan atau Tjikopo Zuid (I, II III), dengan "nomor perang" 1945, 1946, 1947, milik Perusahaan Perkebunan Tjikopo Selatan (Cultuurmaatschappij Tjikopo-Zuid) di Batavia.

Perkebunan Cikopo Selatan tahun 1939 diambil alih Pemerintah Belanda dan dikelola Pusat Perkebunan Belanda. Tahun 1954 Cikopo Selatan dan Gunung Mas digabungkan setelah keduanya diambil alih N.V. Tiedemant E. Van Kerchem (TVK), berkantor pusat di Bandung. Pada 30 Desember 1958, N.V. TVK dinasionalisasi dan diserahkan kepada Perusahaan Perkebunan Nusantara (PPN) Baru Kesatuan Jawa Barat (Jabar) II. Kemudian 1959, Perancis mengambil alih Gunung Mas kembali dan menyerahkan kepada PT Gede Bagja yang berlokasi di Bogor. Pada 15 Desember 1962, Pemerintah RI mengambil alih kembali dan pengelolaannya diserahkan kembali 
kepada PPN Baru Kesatuan Jawa Barat II. Antara tahun 1963-1964 terjadi reorganisasi daerah kerja sehingga Perkebunan Gunung Mas dan Cikopo Selatan dimasukkan ke dalam PPN Aneka Tanaman VII. Tahun 1970 dimasukkan ke Perusahaan Perkebunan Negara (PPN) yang berubah menjadi PNP XII. Berdasarkan PP No. 25 tahun 1971, status PNP XII berubah menjadi PT. Perkebunan XII (persero), 1 Agustus 1971 (Nuralia dkk., 2013).

Pada tahun 1972 Gunung Mas dan Cikopo Selatan digabungkan dalam satu manajemen kebun dengan nama Perkebunan Gunung Mas, karena Pabrik
Kemudian Cikopo Selatan menjadi salah satu bagian kebun Gunung Mas bernama Afdeling Cikopo Selatan. Terhitung 11 Maret 1996 diadakan penggabungan tiga PTP (XI, XII, XIII) menjadi PTP Nusantara VIII meliputi Jawa Barat dan Banten. Perkebunan Gunung Mas berada dibawah PTPN VIII, berkantor Pusat di Jalan Sindang Sirna No. 4, Bandung.

Perkebunan Gunung Mas dalam penataan ruang Kawasan Bogor, Puncak, dan Cianjur (Bopuncur) sesuai Keppres No 114/1999, masuk ke dalam kawasan lindung dan kawasan penyangga, sehingga berperan juga

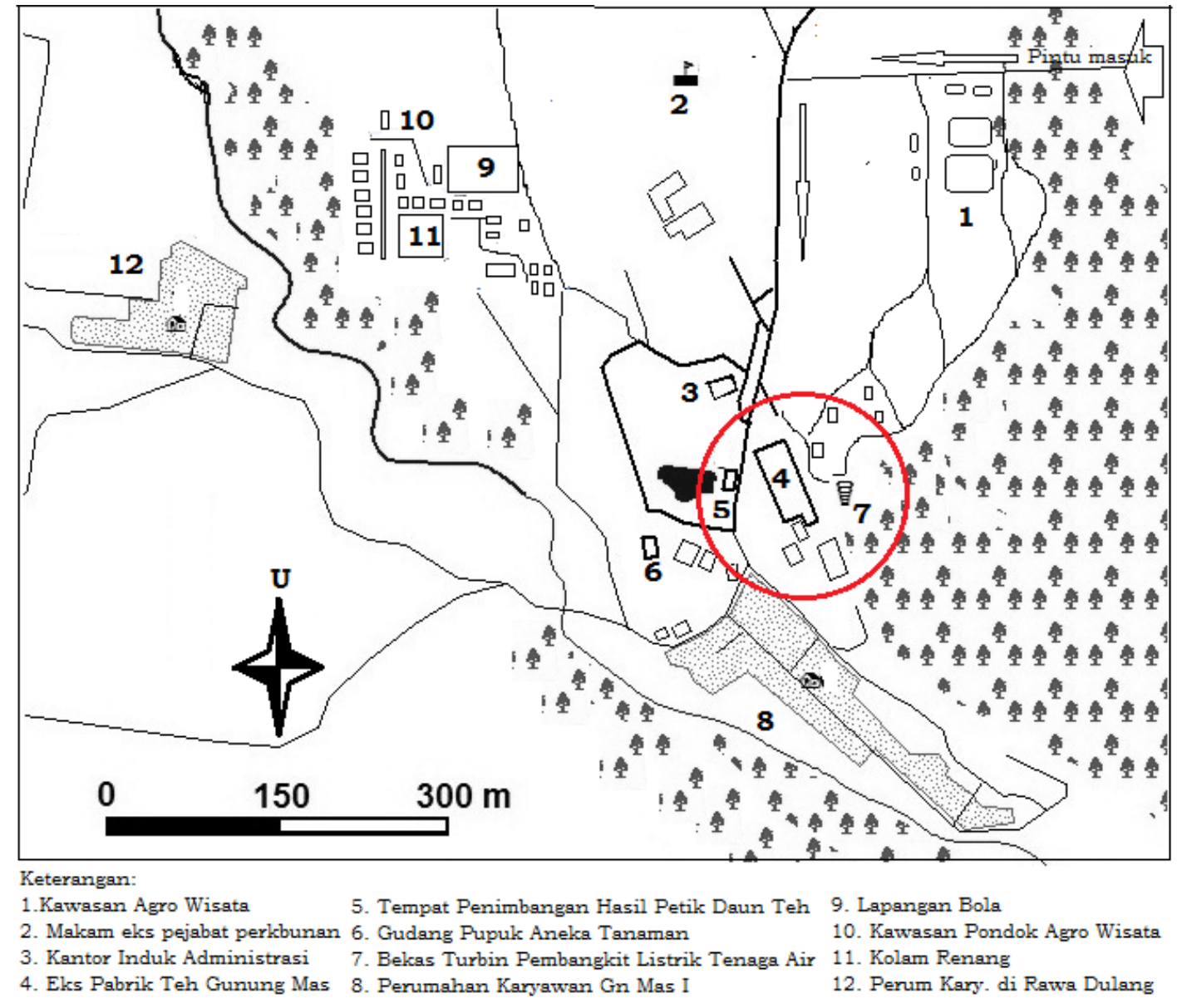

Gambar 2: Lokasi bekas Pabrik Teh Gunung Mas (4) di Peta Wilayah Emplasemen Perkebunan Gunung Mas (Sumber: Dokumen Nuralia dkk., 2013 dimodifikasi oleh Nuralia tahun 2018).

Pengolahan Teh Perkebunan Cikopo Selatan mengalami kebakaran. sebagai kawasan dalam pelestarian lingkungan alam. Perkebunan Gunung 
Mas mempunyai 3 afdeling kebun, yaitu Afdeling Gunung Mas I (492,77 Ha), Afdeling Gunung Mas II (423,87 ha), dan Afdeling Cikopo Selatan (1850,05 ha) yang terdiri dari 469,02 ha untuk bagian Cikopo Selatan I dan 292,29 ha untuk bagian Cikopo Selatan II (Mugiyanto, 2004: 6-7).

\section{Deskripsi Singkat Bekas Pabrik Teh Gunung Mas}

Bekas pabrik teh Gunung Mas berada di Emplasemen Kantor Induk Administrasi Kebun Gunung Mas (lihat Gambar 2). Secara administratif termasuk Desa Tugu Selatan, Kecamatan Cisarua, Kabupaten Bogor. Secara geografis terletak terletak dalam koordinat $06^{\circ} 42^{\prime} 34,61^{\prime \prime}$ LS dan $106^{\circ} 58^{\prime} 04,67^{\prime \prime}$ BT, dengan ketinggian 1159 meter di atas permukaan laut.

Perkebunan Teh Gunung Mas terletak di wilayah Bogor, $\pm 28 \mathrm{Km}$ dari Stasiun Bogor, di pinggir jalan raya dari Bogor menuju Puncak Cianjur. Pemilik awal adalah "Thung Siang Kong Bogor", Societe de Cultures Gunung Mas di Paris. Sementara itu, Perkebunan Cikopo Selatan (termasuk Cikopo Panjang) didirikan oleh perusahaan N.V. Cult. Mijn. Tjikopo Selatan Djakarta, terletak di Bogor \pm 18 $\mathrm{Km}$ dari Stasiun Borgor, pinggir jalan dari Gadok ke Pasir Muncang (Ismet, 1970: 114-115) .

Bangunan pabrik teh sudah tidak beroperasi sejak tahun 2013 sampai sekarang, tetapi masih berdiri kokoh dan dirawat cukup baik. Bangunan ini sejak pertama didirikan di tahun 1910 secara keseluruhan tidak mengalami banyak perubahan bentuk dan

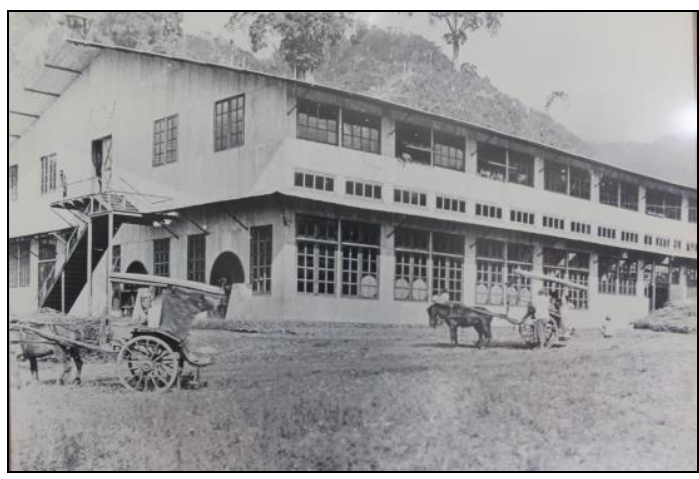

Gambar 3: Pabrik Teh Gunung Mas Tahun 1910 (Dok. Dedi Ruswandi, Karyawan Perkebunan Gunung Mas, 2018 : Sumber: Dokumen Kantor Induk Administrasi Perkebunan Gunung Mas, 2018)

arsitektur. Perubahan terjadi di bentuk tangga dan jendela bagian muka, tata ruang dalam, serta pintu masuk ke Tea Gallery. Hal ini dapat diketahui dari foto lama tahun 1900-an dan foto terbaru di tahun 2018, serta denah bangunan (lihat Gambar 3, 4, 5, 6).

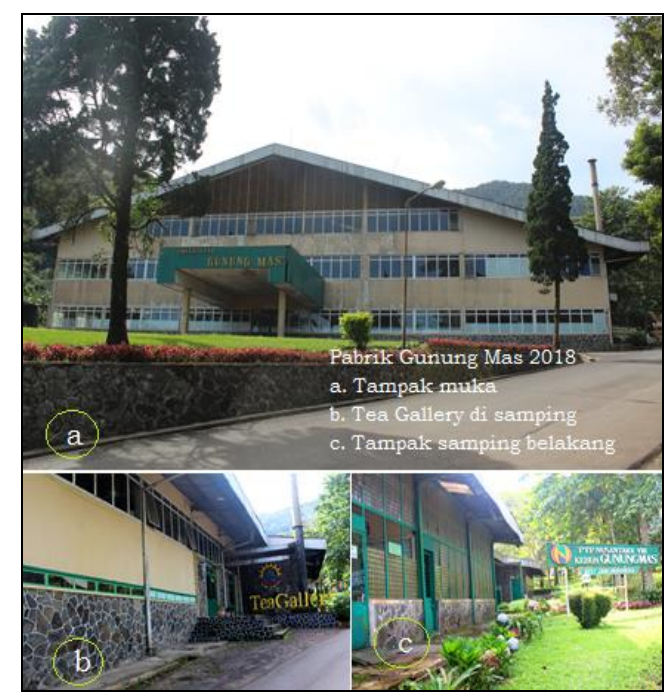

Gambar 4: Pabrik Teh Gunung Mas Tahun 1910 (Sumber: Dokumen Ruswandi, 2018)

Bangunan pabrik berdenah dasar persegi panjang dengan gaya arsitektur modern Eropa atau Hindia Baru, suatu gaya campuran antara unsur-unsur arsitektur Eropa Modern dipadu dengan gaya lokal (tradisional Indonesia). Gaya 
Eropa terlihat di volume bangunan secara keseluruhan, jendela dan pintu yang besar, serta ketebalan dinding bangunan yang khas Eropa, kokoh dan sangat megah. Sementara itu, gaya lokal terlihat dari bentuk atap kampung atau jolopong (Sunda) dengan atap tumpang dua, serta banyaknya bukaan untuk penerangan alami dan sirkulasi udara lantai 1 atau tanpa tangga naik ke lantai 2. Pada dinding bagian bawah diperkuat dengan belahan batu kali sehingga menjaga kekokohan bangunan. Selain itu, ada penambahan bagian bangunan dan perubahan tata ruang yang disesuaikan dengan fungsi pengolahan teh di pabrik (lihat gambar 4 dan 5).

Pada awalnya pabrik Gunung

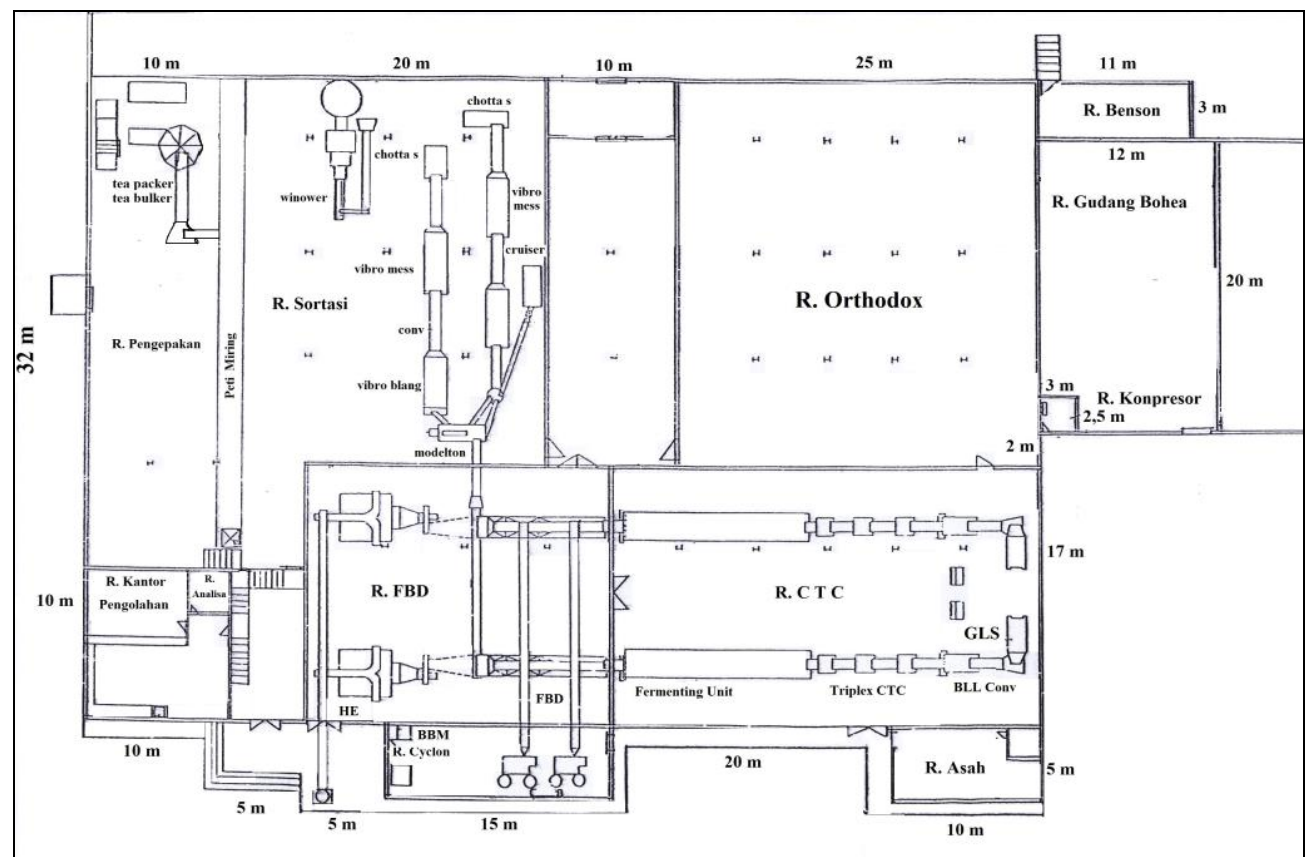

Gambar 5: Denah Pabrik Teh Perkebunan Gunung Mas Lantai 1 (Sumber: Laporan Penelitian, 2013)

(lihat gambar 4).

Bangunan bekas pabrik tampak masih asli, walaupun ada beberapa perubahan. Menurut karyawan Perkebunan Gunung Mas (Dedi Ruswandi, 2018), bangunan pabrik pernah direnovasi sekitar tahun 1980an. Beberapa jendela diperbarui dan bentuknya berubah dari kaca berpanil atau dibagi menjadi beberapa bagian menjadi tanpa panil, atap kanopi yang menempel di deretan jendela kaca lantai 1 dihilangkan, pintu masuk di bagian depan yang awalnya bertangga naik ke lantai 2 diganti dengan pintu masuk ke
Mas mengolah daun teh dengan mesin orthodox, kemudian diganti dengan mesin CTC antara tahun 1980-1990-an. Kedua mesin sama-sama menghasilkan teh hitam, yang membedakannya adalah bentuk hasil jadinya, partikel tehnya berbeda. Penggantian mesin tersebut yang mengharuskan tata ruang dalam bangunan sedikit berubah, dan ada penambahan bangunan untuk keperluan tersebut (Dedi Ruswandi, 2018). Kemudian bangunan bagian belakang sudah banyak yang rusak, terutama di lantai ke-1 tempat pengeringan daun teh. Tampak kipas angin untuk 
membantu proses pengeringan daun teh, sudah rusak dan tidak difungsikan lagi.

Kontruski bangunan pabrik pada awalnya dinominasi oleh bahan besi bertulang, seng, dengan dinding plesteran cor/semen. Tampak depan dan samping dilengkapi susunan ventilasi kaca memenuhi dinding. Pintu masuk bagian depan berupa tangga naik ke lantai dua. Atap berbentuk atap kampung (jolopong) dengan bahan penutup seng ditopang dengan rangka besi. Konstruksi bangunan setelah renovasi sedikit mengalami perubahan, seperti yang telah dijelaskan sebelumnya. karyawan Kebun Gunung Mas, mesin CTC pun sudah tidak ada lagi di eks pabrik, sudah diangkut dan diberikan ke kebun seinduk untuk digunakan. Akan tetapi, sekat-sekat ruangan atau tata ruang dalam/denah ruangan (lihat gambar 5 dan 6) dalam bangunan eks pabrik Kebun Gunung Mas masih sama sebagai bangunan dua lantai sebagai berikut.

Bangunan lantai bawah eks pabrik terdiri dari: 1) Ruang Penggilingan (fermentasi) atau ruang Crushing Tearling Curling (memotong, merobek, menggulung) atau ruang CTC; 2) Ruang Pengeringan atau Fluid

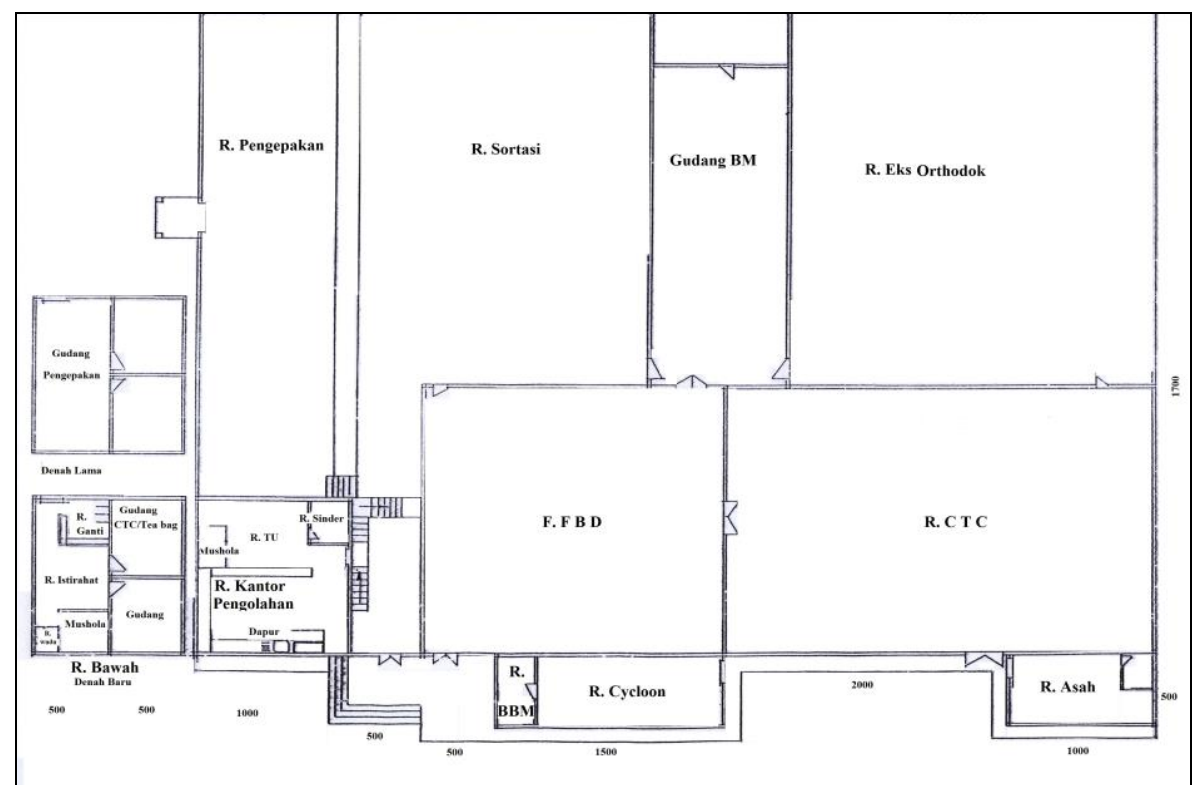

Gambar 6: Denah Pabrik Teh Gunung Mas Lantai Atas (Sumber: Laporan Penelitian, 2013)

Pabrik teh Gunung Mas menggunakan mesin CTC yang sudah berupa mesin modern tahun 1987, setelah pabrik direnovasi dua kali (revisi tahun 1970 dan 1980). Mesin pengolahan teh Gunung Mas lama zaman Belanda (mesin orthodox) sudah tidak ada dan tidak ada informasi tentang keberadaannya. Informasi terakhir dari
Bed Dryer atau ruang FBD; 3) Ruang Sortasi atau ruang Grading untuk pemilahan jenis teh (grade 1, 2, 3 dan seterusnya); 4) Ruang Pengepakan hasil jadi berupa bulk (teh curah), yang disimpan di wadah berupa paper sack atau karung untuk memudahkan dalam proses penjualan atau penyimpanan; 5) Ruang Cyclone/HE; 6) Ex Ruang Teh 
Orthodox; 7) Ruang Asah; dan 8) Ruang Bengkel Umum

Tata letak bangunan pabrik di dalam permukiman emplasemen perkebunan tahun 2013 menunjukkan ada pengelompokkan dan pemisahan antar bangunan, sesuai dengan fungsi (lihat gambar 2). Bangunan pabrik (4) berada di tengah-tangah antara kantor administrasi (3) dan perumahan karyawan (8). Sementara, perumahan pejabat perkebunan berdiri terpisah dan berpola menyebar atau tidak mengelompok seperti perumahan karyawan kebun. Akan tetapi, sekarang ini rumah dinas para pejabat perkebunan tidak terletak di lokasi permukiman emplasemen.

Tabel 1. Bentuk, Arsitektur, Bahan, Teknologi Eks Pabrik Gunung Mas Sebelum Renovasi (1910-1970)

\begin{tabular}{|c|c|c|c|}
\hline Komponen & Bentuk & Bahan & Teknologi \\
\hline Pondasi & Persegi & Batu & massif \\
\hline Pintu & $\begin{array}{l}\text { Persegi } \\
\text { panjang }\end{array}$ & Besi & $\begin{array}{l}\text { Sambungan } \\
\text { mur dan baud }\end{array}$ \\
\hline Tangga & Panjang & Besi & $\begin{array}{l}\text { Sambungan } \\
\text { mur dan baud }\end{array}$ \\
\hline Jendela & Persegi & $\begin{array}{l}\text { Kaca } \\
\text { berpanil 1, } \\
8,12\end{array}$ & $\begin{array}{l}\text { Sambungan } \\
\text { mur dan baud }\end{array}$ \\
\hline Ventilasi & Persegi & $\begin{array}{l}\text { Kaca } \\
\text { berpanil }\end{array}$ & $\begin{array}{l}\text { Sambungan } \\
\text { mur dan baud }\end{array}$ \\
\hline $\begin{array}{l}\text { Dinding } \\
\text { Atas }\end{array}$ & Tembok & Bata merah & plester semen \\
\hline $\begin{array}{l}\text { Dinding } \\
\text { Bawah }\end{array}$ & Tembok & Bata merah & plester semen \\
\hline $\begin{array}{l}\text { Kusen } \\
\text { Jendela }\end{array}$ & Persegi & Kayu & $\begin{array}{l}\text { Sambungan } \\
\text { mur dan baud }\end{array}$ \\
\hline Kusen pintu & $\begin{array}{l}\text { Persegi } \\
\text { panjang }\end{array}$ & & $\begin{array}{l}\text { Sambungan } \\
\text { mur dan baud }\end{array}$ \\
\hline $\begin{array}{l}\text { Konstruksi } \\
\text { bangunan }\end{array}$ & $\begin{array}{l}\text { bentuk atap } \\
\text { rumah } \\
\text { kampung }\end{array}$ & $\begin{array}{l}\text { Besi } \\
\text { bertulang }\end{array}$ & $\begin{array}{l}\text { Sambungan } \\
\text { mur dan baud }\end{array}$ \\
\hline Atap & $\begin{array}{l}\text { Benutk atap } \\
\text { rumah } \\
\text { kampung }\end{array}$ & Besi, seng & $\begin{array}{l}\text { Sambungan } \\
\text { mur dan baud }\end{array}$ \\
\hline $\begin{array}{l}\text { Penutup } \\
\text { Atap }\end{array}$ & $\begin{array}{l}\text { Bentuk atap } \\
\text { rumah } \\
\text { kampung }\end{array}$ & Seng & $\begin{array}{l}\text { Sambungan } \\
\text { mur dan baud }\end{array}$ \\
\hline
\end{tabular}

Tabel 2. Bentuk, Bahan, Teknologi Eks Pabrik Gunung Mas Setelah Renovasi (1970, 1980, 2013-2018)

\begin{tabular}{|c|c|c|c|}
\hline Komponen & Bentuk & Bahan & Teknologi \\
\hline Pondasi & Persegi & Batu & massif \\
\hline Pintu & $\begin{array}{l}\text { Persegi } \\
\text { panjang }\end{array}$ & Besi & $\begin{array}{l}\text { Sambungan } \\
\text { mur dan } \\
\text { baud }\end{array}$ \\
\hline Tangga & Tidak ada & Tidak ada & $\begin{array}{l}\text { Sambungan } \\
\text { mur dan } \\
\text { baud }\end{array}$ \\
\hline Jendela & $\begin{array}{l}\text { Persegi } \\
\text { panjang }\end{array}$ & $\begin{array}{l}\text { Kayu, kaca } \\
\text { tanpa panil }\end{array}$ & $\begin{array}{l}\text { Sambungan } \\
\text { mur dan } \\
\text { baud }\end{array}$ \\
\hline Ventilasi & Persegi & $\begin{array}{l}\text { Kayu, kaca } \\
\text { tanpa panil }\end{array}$ & $\begin{array}{l}\text { Sambungan } \\
\text { mur dan } \\
\text { baud }\end{array}$ \\
\hline $\begin{array}{l}\text { Dinding } \\
\text { Atas }\end{array}$ & persegi & Bata merah & $\begin{array}{l}\text { plesteran } \\
\text { semen }\end{array}$ \\
\hline $\begin{array}{l}\text { Dinding } \\
\text { Bawah }\end{array}$ & Persegi & $\begin{array}{l}\text { Batu kali } \\
\text { bulat pipih } \\
\text { cenderung } \\
\text { tdk } \\
\text { beraturan }\end{array}$ & $\begin{array}{l}\text { Perekat } \\
\text { semen }\end{array}$ \\
\hline Kusen & $\begin{array}{l}\text { Persegi } \\
\text { panjang }\end{array}$ & kayu & $\begin{array}{l}\text { Sambungan } \\
\text { mur dan } \\
\text { baud }\end{array}$ \\
\hline $\begin{array}{l}\text { Rangka } \\
\text { Atap }\end{array}$ & $\begin{array}{l}\text { Bentuk } \\
\text { atap rumah } \\
\text { kampung }\end{array}$ & besi & $\begin{array}{l}\text { Sambungan } \\
\text { mur dan } \\
\text { baud }\end{array}$ \\
\hline Atap & $\begin{array}{l}\text { Bentuk } \\
\text { atap rumah } \\
\text { kampung }\end{array}$ & Besi, seng & $\begin{array}{l}\text { Sambungan } \\
\text { mur dan } \\
\text { baud }\end{array}$ \\
\hline $\begin{array}{l}\text { Penutup } \\
\text { Atap }\end{array}$ & $\begin{array}{l}\text { Bentuk } \\
\text { atap rumah } \\
\text { kampung }\end{array}$ & Seng & $\begin{array}{l}\text { Sambungan } \\
\text { mur dan } \\
\text { baud }\end{array}$ \\
\hline
\end{tabular}

\section{Komunikasi Nonverbal Dalam Bangunan Pabrik Teh Gunung Mas sebagai Simbol Kejayaan Perkebunan Teh di Indonesia}

Keberadaan perkebunan besar merupakan usaha pertanian dalam skala besar dan kompleks, menyangkut masalah tanah, tenaga kerja, modal, teknologi, dan lain sebagainya (Kartodirdjo dan Surjo, 1991: 4). Keadaan tersebut membutuhkan teknologi modern dan sumber manusia (SDM) yang lebih baik dari segi ilmu dan keterampilan (skill). Setelah dikeluarkannya Undang-Undang Gula dan Undang-undang Agraria (21 Juli, Staatsblad 136 dan 9 April 1870, Staatsblad 55) (Boomgaard, 2004: 64 dan Nuralia, 2016: 3), sebagian besar 
Tuan Tanah (Landheer) dan Administratur (administrateur) adalah para pengusaha swasta asing (Eropa dan Cina). Mereka memiliki SDM dan skil yang dibutuhkan. Keadaan tersebut tampak juga dari visualisasi bentuk dan arsitektur bangungan rumah tinggal mereka yang memuat unsur-unsur arsitektur Eropa dan Cina dengan teknologi modern. Demikian juga dengan bangunan pabrik pengolahan teh, memuat unsur-unsur arsitektur Eropa dan lokal serta teknologi modern, yang disesuaikan dengan keadaan iklim dan lingkungan alamnya. Gaya campuran ini sering disebut sebagai Gaya Hindia Baru.

Gaya Hindia Baru disebut Arsiktektur Kolonial sebagai gaya campuran atau gaya Indis yang telah disesuaikan dengan iklim dan lingkungan sekitarnya (Soekiman, 2003: 3). Gaya ini bisa juga disebut gaya Indo Eropa atau Indo-European Style. Karakter Arsitektur Kolonial dapat dikategorikan dalam 3 periode, yaitu: (1) 1870-1902, (2) 1902-1920, dan (3) 1920-1940. Pada periode 1870-1902 masih mewarisi gaya abad sebelumnya disebut Indische Empire Style. Karakter khasnya tampak pada penggunaan kolom-kolom klasik dan denah simetri penuh. Pada periode kedua (1902-1920an) sangat dipengaruhi ide-ide kaum liberal di negeri Belanda untuk menerapkan Politik Etis di tanah jajahan. Pada periode ini gaya arsitektur lebih mengedepankan fungsi, kolomkolom dan ornament megah perlahan ditinggalkan, sehingga disebut juga sebagai arsitektur peralihan (Arsitektur Transisi), yang menerapkan perpaduan antara Indische Empire Style dan IndoEuropean Style. Kemudian rumah yang dibangun setelah tahun 1920-an menjadi saksi jejak arsitektur rumah Belanda di periode ketiga (1920-1940-an), dikenal sebagai Indo-European Style atau Arsitektur Hindia Baru, dengan ciri khas telah memperkenalkan modernisme. Dalam perkembangan arsitektur di Hindia Belanda dikenal sebagai gaya ekletisisme (Handinoto, 1996: 132-133).

Gaya arsitektur bangunan pabrik teh Gunung Mas bisa dikategorikan sebagai gaya Hindia Baru masa peralihan atau Arsitektur Transisi. Gaya Arsitektur Transisi bangunan pabrik berbeda dengan rumah tinggal pada masa gaya yang sama. Ada dua hal yang menonjol, yaitu tampak dalam kesederhanaan gaya dan keutamaan fungsi. Kesederhanaan tampak dalam bentuk bangunan dan bukaan, kemudian tidak ada ada ornament atau ragam hias seperti halnya rumah tinggal. Fungsinya hanya satu sebagai pabrik pengolahan daun teh segar menjadi teh siap seduh, melalui proses pengolahan dan pengepakan. Selajutnya unsur-unsur langgam Art Deco ditunjukkan oleh deretan jendela persegi yang terdiri dari beberapa deret atau tingkat. Jendela sebagai bukaan berfungsi sama sseperti ventilasi, sebagai penerangan alami dan sirkulasi udara.

Tampak bangunan merupakan visualisasi suatu artifak atau fitur sebagai bentuk komunikasi nonverbal. Bangunan pabrik adalah hasil seni dan teknologi ditinjau dari arsitektur bangunan. Hasil seni/teknologi banyak memberi isyarat yang mengandung arti, 
baik yang melekat di bangunan (bentuk dan arsitektur) maupun cerita sejarahnya. Pabrik ketika itu juga bukan hanya berfungsi dalam produksi teh, tetapi juga sebagai sebuah pesan dimana setiap objek menunjukkan identitas pemilik dan keadaan sosial ekonomi pada zamannya.

Volume bangunan pabrik secara visualisasi tampak besar dan megah sebagai bangunan dua lantai dengan banyak bukaan (jendela). Secara logika menunjukkan bahwa hasil petik daun teh yang diolah di pabrik jumlahnya sangat banyak, karena memerlukan ruang besar. Banyaknya hasil petik daun teh menunjukkan luasnya kebun the yang dikelola sebagai penyedia bahan mentah. Luasny areal perkebunan menunjukkan sebagai perusahaan besar dengan modal besar juga. Secara otomatis hasil yang diperoleh sebagai keuntungan perusahaan juga besar. Dengan demikian, keuntungan yang besar menunjukkan bahwa teh adalah tanaman komoditas ekspor yang laku di pasaran internasional, sebagai puncak kejayaan perkebunan teh di Indonesia.

$$
\text { Masa-masa kejayaan }
$$

perkebunan swasta asing di Hindia Belanda identik dengan periode puncak keemasan kolonialisme. Bangunan Belanda yang ditemukan sekarang pada dasarnya mengikuti bangunan yang ada sebelumnya dengan teknologi sederhana atau tradisional. Yang diubah adalah penggunaan teknik, material batu, besi dan seng atau genteng. Hal ini tampak pada bangunan rumah tinggal yang disebut landhuizen, yang terkenal saat itu adalah Arsitek Wolff Schoemaker, DW Berrety, dan Cardeel.
Sebelum kedatangan Belanda, sebenarnya sudah banyak bangsabangsa lain yang lebih dahulu datang ke Indonesia antara lain dari Cina, India, Vietnam, Arab, dan Portugis, yang memberi pengaruh pada budaya asli. Karena itu, dalam bangunan Indis juga terkandung berbagai macam unsur budaya tersebut. Faktor-faktor lain yang ikut berintegrasi dalam proses perancangan antara lain faktor lingkungan, iklim atau cuaca, tersedia material, teknik pembuatan, kondisi sosial politik, ekonomi, kesenian, dan agama.

Bentuk rumah bergaya Indis sepintas tampak seperti bangunan tradisional dengan atap berbentuk Joglo Limasan. Bagian depan berupa selasar terbuka sebagai tempat untuk penerimaan tamu. Kamar tidur terletak pada bagian tengah, di sisi kiri dan kanan, sedang ruang yang terapit difungsikan untuk ruang makan atau perjamuan makan malam. Bagian belakang terbuka untuk minum teh pada sore hari sambil membaca buku dan mendengarkan radio, merangkap sebagai ruang dansa.

Penggunaan kata Indis untuk gaya bangunan seiring dengan semakin populernya istilah Indis di berbagai macam institusi, seperti Partai Indische Bond atau Indische Veeneging. Arsitektur Indis merupakan asimilasi atau campuran dari unsur-unsur budaya Barat terutama Belanda dengan budaya Indonesia khususnya dari Jawa. Dari segi politis, pengertian arsitektur Indis juga dimaksud untuk membedakan dengan bangunan tradisional yang lebih dahulu telah eksis, bahkan oleh 
Pemerintah Belanda bentuk bangunan Indis dikukuhkan sebagai gaya yang harus ditaati, sebagai simbol kekuasaan, status sosial, dan kebesaran penguasa saat itu.

Industri perkebunan teh di Jawa Barat terpancang mantap. Produksi teh terus meningkat dalam kurun waktu 1895-1939. Pada tahun 1890 produksi teh berjumlah 3.500 ton, tahun 1910 meningkat pesat menjadi 12.500 ton, kemudian tahun 1930 menjadi 46.000 ton. Produksi teh terus meingkat sepanjang Zaman Malaise, juga sewaktu harga penjualan sangat merosot (O’Malley, 1988: 220).

Konteks masa lalu tentang sejarah kolonialisme dan imperialisme di Indonesia secara umum dipandang sebagai sejarah perkebunan itu sendiri (O’Malley, 1988 dalam Nuralia, 2015 dan Nuralia, 2017: 13). Pola perkebunan yang dikenalkan pemerintah kolonial secara umum sebenarnya telah berhasil meningkatkan taraf kehidupan penduduk pribumi, yang awalnya hanya menggantungkan hidup kepada pola tanam tradisional. Petani di Priangan khususnya memiliki tingkat kesejahteraan yang lebih baik apabila dibandingkan dengan petani di Jawa Tengah dan Jawa Timur. Hal ini dikarenakan hasil kebun kopi, kina, dan teh di Priangan menjadi komoditas ekspor primadona pasar dunia. Selain itu, petani Priangan juga mendapat keistimewaan, karena tidak terjamah sistem tanam pakas, serta kebutuhan akan beras dipenuhi oleh pemerinatah kolonia. Keadaan petani Priangan tersebut bisa dianggap kehidupan cukup sejahtera dan makmur. Salah satu indikasi kemakmuran adalah tidak adanya perlawanan rakyat selama abad ke-19 di Priangan khususnya.

Melihat kondisi perkebunan teh dewasa ini, Mumuh mengaku amat prihatin. Potensi yang begitu besar tak bisa tergarap dengan optimal. Jika pada abad ke-19 Hindia-Belanda menjadi pengekspor terbesar kopi dan kina dunia, kini kemunduran terus terjadi. Demikian halnya dengan komoditas teh yang tak kalah potensial.

\section{PENUTUP}

Bangunan eks pabrik the Gunung Mas secara keseluruhan masih tampak utuh dan kokoh. Bangunan dengan denah dasar persegi panjang sebagai bangunan dua lantai, menampakkan kebesaran dan kekokohannya. Kemudian bahan dan teknologi yang digunakan membuktikan bahwa pada masanya, pabrik didirikan terencana dengan baik. Sebagai bangunan produksi atau pengolahan bahan baku pucuk daun teh, bangunan pabrik tersebut memiliki ruang-ruang khusus sesuai fungsi, yang selaras dengan proses pengolahan bahan pucuk di pabrik.

Bangunan pabrik teh tersebut memiliki luas yang besar dengan jumlah ruang yang banyak, memberi informasi bahwa produk bahan mentah pucuk daun the yang dioleh sangat banyak. Dengan demikian, produksi yang dihasilkan oleh pabrik the Gunung Mas berjumlah besar dan menjadi komoditas ekspor yang laku di pasaran dunia. Secara otomastis memberi penjelasan bahwa keuntungan yang diraih oleh perusahaan sangat besar, yang 
menunjukkan puncak kejayaan awal abad ke-20.

komoditas teh di Hindia Belanda pada

\section{DAFTAR PUSTAKA}

Arsip. Almanak Arsip Belanda. Staatsblad van Nederlandsch-Indie 1920 No. 723. (Het Nieuwes van den dag voor Nederlandsch-Indie, 11-11-20). Den Haag: Gehetna-archief.

Boomgaard, Peter. 2004. Anak Jajahan Belanda, Sejarah Sosial dan Ekonomi Jawa 1795-1880. Terjemahan Monique Soesman, Keosalah Soebagyo Toer. Jakarta : KITLV-Jakarta dan Djambatan.

Handinoto, 2010. Arsitektur dan Kota-Kota di Jawa pada Masa Kolonial. Yogyakarta: Graha Ilmu.

Handinoto. 1996. Perkembangan Kota dan Arsitektur Kolonial Belanda di Surabaya 1870-1940. Yogyakarta: Lembaga Penelitian dan Pengabdian Kepada Masyarakat Universitas Kristen Petra Surabaya, Amdi Offset.

Ismet. 1970. Daftar Tanah-Tanah Perkebunan ${ }^{2}$ Di Indonesia (The List Of Estates Throughout Indonesia). Bandung: Biro Sinar C.V.

Kartodirdjo, Sartono dan Djoko Surjo. 1991. Sejarah Perkebunan di Indonesia: Kajian Sosial Ekonomi. Yogyakarta: Aditya Media.

Nuralia, Lia. 2017. Struktur Sosial dan Nilai-Nilai Kolonial pada Rumah Pejabat Tinggi Perkebunan Peninggalan Belanda di Jawa Bagian Barat, dalam Jurnal Kapata Arkeologi. Vol 13 No 1 Juli 2017

Nuralia, Lia. 2016. Situs Perkebunan Karet Cisaga di Kabupaten Ciamis 1908-1972: Kajian Arkeologi Industri Tentang Kode Budaya Kolonial. Tesis. Depok: Program Studi Arkeologi, Fakultas Ilmu Pengetahuan Budaya, Universitas Indonesia.

Nuralia, Lia. 2015. Permukiman Emplasemen Perkebunan Batulawang di Afdeling Lemahneundeut di Ciamis, Jawa Barat. Dalam Jurnal Purbawidya Vol. 5 No. 1, Juni 2015. Hal. 29-48.

Nuralia, Lia dkk. 2013. Bangunan Kolonial Perkebunan Gunung Mas, Kabupaten Bogor dan Sekitarnya, Provinsi Jawa Barat. Laporan Penelitian Arkeologi. Bandung: Kementerian Pendidikan dan Kebudayaan, Pusat Arkeologi Nasional, Balai Arkeologi Bandung (tidak diterbitkan).

Wardini, Cici dan Galih Permadi, Muhammad Iqbal, Novie Widianti. 2010. Dari Bumi Pasundan Menembus Dunia, Perjalanan Panjang PT Perkebunan Nusantara VIII. Bandung: PTPN VIII.

O’Malley, William J. 1988. "Perkebunan 1830-1940: Ikhtisar". Dalam Anne Booth, William J. O’Malley, Anna Weidermann (Penyunting), Sejarah Ekonomi Indonesia, Jakarta: LP3ES.

Pearce, Susan M. (Edited), 2003. Interpreting Objects and Collections. London and New York: Routledge. 
Wulan, Roro Retno. 2015. "Komuniskasi NonVerbal Bangunan Kolonial Di Perkebunan Teh Jawa Barat", dalam Jurnal Sosioteknologi Vol. 14, No. 3, Desember 2015.

Suganda, Her. 2014. Kisah Para Preanger Planters. Jakarta: PT Kompas Media Utama.

Selayang Pandang Perkebunan Gunung Mas. 2013. Bogor: Kantor Induk Administrasi Perkebunan Gunung Mas.

Sukiman, Djoko. 2011. Kebudayaan Indis, Dari Zaman Kompeni Sampai Revolusi. Depok: Komunitas Bambu. 